\title{
Statistical comparison of the internal validity (sensitivity, specificity and safety) of three anthropometric indices used in the diagnosis of pathological nutritional situations overweight and obesity
}

DOI: 10.46932/sfjdv2n1-078

Received in: November 1st, 2020

Accepted in: December 30th, 2020

\author{
José Franco-Monsreal \\ Doctor en Ciencias Médicas \\ E-mail: jose.franco@uimqroo.edu.mx \\ David Gustavo Ku-Polanco \\ Licenciado en Salud Comunitaria \\ E-mail: david_gustavo_ku@hotmail.com
Lidia Esther del Socorro Serralta-Peraza
Maestra en Educación
E-mail: lidia.serralta@uimqroo.edu.mx \\ María Selene Sánchez-Uluac \\ Maestra en Ciencias \\ E-mail: biosele@hotmail.com
}

\begin{abstract}
According to the World Health Organization, obesity is growing at an alarming rate, as it is now estimated that more than 250 million people are obese in the world, or $7 \%$ of the adult population. Obesity is defined as a generally chronic multifactorial pathological entity manifested by a condition of excess body fat associated with many chronic-degenerative conditions and disorders, mostly treatable. To compare the internal validity (sensitivity, specificity and safety) of the Body Mass Index versus the internal validity of the Waist/Hip Index versus the internal validity of the Abdominal Circumference as diagnostic methods of overweight and obesity in adults aged 18-64 years of either gender who attended the Integral Hospital "Jose Maria Morelos" in the Mayan municipality of Jose Maria Morelos, Quintana Roo, Mexico, during the period comprised from 1 August 2017 to 31 July 2018. The study design corresponds to that of a descriptive observational epidemiological study without directionality and with prospective temporality. A total of 300 observation units [119 (39.67\%) of the male gender and $181(60.33 \%)$ of the female gender] of 18-64 years of age were studied in the period from August 1, 2017 to July 31, 2018. Mantel-Haenszel Ji-Square statistic $(\mathrm{x} 2 \mathrm{M}-\mathrm{H})$ was used as hypothesis test or statistical significance test. The software Epi lnfo for Windows, Version 7.1.5.2, was used to obtain the values of the statistic $\mathrm{x} 2 \mathrm{M}-\mathrm{H}$ and of the probabilities (p). According to Norma Oficial Mexicana NOM-174-SSA1-1998, 171 (57.00\%) observation units with overweight and obesity were tagged and $129(43.00 \%)$ observation units without overweight and obesity were tagged. The diagnostic test with the highest sensitivity $(82.46 \%)$ was the Body Mass Index; the diagnostic test with the greatest specificity (58.14\%) was the Waist/Hip Index; and the diagnostic test with the highest safety $(70.67 \%)$ was also the Body Mass Index.
\end{abstract}

Keywords: Internal validity, anthropometric indices, overweight and obesity. 


\section{INTRODUCTION AND BACKGROUND}

According to the World Health Organization (WHO), obesity is growing alarmingly, since today it is estimated that more than 250 million people are obese in the world, that is, $7 \%$ of the adult population. Obesity is defined as a generally chronic multifactorial disease entity manifested by a condition of excess body fat associated with many chronic-degenerative conditions and life disorders, most of which are treatable ${ }^{[1-3]}$.

It is one of the most frequent metabolic and nutritional alterations. It is undoubtedly an important public health problem in Mexico since it affects more than $30 \%$ of the adult population in our country. Because of the high number of people who suffer from it, because of the risk that it implies in the biological, psychological and social spheres in the individual, as well as because of the physical disability that it causes leads to an increased risk of premature death in a high percentage. It also generates significant economic losses ${ }^{[4-6]}$.

Various studies have revealed important data. These studies were carried out in Mexico City in 1967 and in the city of Merida in 1968 and 1989. The latter highlight the importance of the fact that in Jose Maria Morelos there is a high prevalence of obesity, as well as a short stature. This is relevant since the first cut-off points for obesity according to the Body Mass Index were based on American literature. With the results of the studies, knowledge about obesity and its diagnostic methods was expanded ${ }^{[7-9]}$.

A real definition and an exact method of diagnosis have not yet been found, so it is important to carry out studies that reveal the real epidemiological situation, since the impact of obesity on health is underestimated. For this reason, it is desired to demonstrate the usefulness of certain diagnostic methods such as the Body Mass Index, the Waist/Hip Index and the Abdominal Circumference that, at the same time, serve as risk indicators for overweight and obesity, which are easy to apply, are reliable for both clinician and patient, and can be easily used in everyday medical care.

Due to its importance in the health area, it is desired to stimulate research on this topic, especially at the regional level, having been, therefore, the general objective of this research to compare the usefulness of the diagnostic methods already mentioned as indicators of overweight and obesity in adults who attended the Integral Hospital "Jose Maria Morelos" of the Mayan municipality of Jose Maria Morelos, Quintana Roo, Mexico, in the period from August 1, 2017 to July 31, 2018.

The available scientific literature does not report the existence of previous studies whose objectives have been the determination of sensitivities, specificities and safety in at least one of the three diagnostic tests studied, therefore it is not possible to statistically compare the corresponding results observed in the present study. 
In the present work, the values indicated in the Norma Oficial Mexicana NOM-174-SSA1-1998 ${ }^{[10]}$ were used as a reference test or Gold Standard: 1 . Overweight and obesity: ( $\geq 20 \%$ overweight); and 2. Without overweight and obesity: ( $\leq 19 \%$ overweight $)$.

Obesity is the excessive accumulation of fat in the body. Except for people who are very muscular, those whose weight exceeds at least $20 \%$ the midpoint of the weight scale according to the standard weight/height value are considered obese. Obesity can be classified as mild (20-40\% overweight), moderate (41-100\% overweight), and severe $(\geq 101 \% \text { overweight })^{[11]}$.

Obesity, by itself, is one of the most frequent metabolic disorders in medical practice and among the most frustrating and difficult to treat. Furthermore, it is a frequent cause of morbidity and mortality. Although some progress has been made in the treatment of obesity in the last 25 years, there have nevertheless been important changes in the understanding of its causes and health implications ${ }^{[12-15]}$.

Obesity is defined as a pathological entity of multifactorial origin that produces multiple complications, which is associated with practically all chronic-degenerative diseases, characterized by excess energy deposits in the form of body fat, which has adverse effects on the health and longevity due to its association, among many other problems, with high blood pressure, lipoproteinemia, type 2 diabetes mellitus, gallstones, osteoarthritis and certain types of cancer. Total body fat should not be more than 10 $20 \%$ in men and 20-30\% in women. Obese or overweight people are considered those who present values above $20 \%$ of their desirable weight according to their height, weight and gender when it is due to fat mass and not due to muscles, water or bones. Similarly, obesity is accepted as excess body fat based on measurements of adipose tissue ${ }^{[16-17]}$.

The prevalence of obesity increases in the world in both children and adults, reaching between 20 and $50 \%$, with women being the most affected with 1.7 for every obese man. It is the most frequent and important nutritional disease in the world. It has been estimated that in the United States of North America it affects about $40 \%$ of the adult population, in Great Britain from a third to half of its population and the developing countries of the Caribbean and South America are having serious increases in obesity. Due to its frequency, in Mexico it constitutes a public health problem and, except for the Norma Oficial Mexicana NOM-174-SSA1-1998, it is not given its place. Statistics reveal that $35 \%$ of the population is obese, particularly in the female gender, and $60 \%$ is overweight, especially in the male gender. However, simplistic views reduce a problem with deeper roots to mere outward appearance. In rural areas the frequency is $4-10 \%$, in suburban areas $12 \%$ and in urban areas $35 \%$ with a ratio of 1.4 women: 1 man. Based on current trends, obesity is forecast to continue to be a public health problem with a marked increase. Recently, the WHO established a twofold growth in the number of severely overweight adults compared to those who are underweight between 1995 and 2025 (WHO 1998). Raw projections, 
extrapolating existing data, suggest that by 2025 obesity levels will be between 45 and $55 \%$ in the United States of America; between 30 and 40\% in Australia, England and India; and over 20\% in Brazil ${ }^{[16-18]}$.

In Mexico, the first epidemiological studies showed that obesity was frequent at puberty and then increased again between 40 and 50 years of age, maintaining this way until 60 years of age, which is when it began to decrease slowly ${ }^{[19]}$.

In older age groups, the lower frequency of obesity reflects the higher mortality at younger ages associated with obesity-related diseases. Likewise, the prevalence of obesity varies with socioeconomic status (even poverty is associated with high obesity, especially in the female gender) and with culture, as it exerts important influences ${ }^{[20-21]}$.

In Merida, a review study carried out by Vargas and Laviada reported that in 1963 there was 6.6\% obesity in men and $21.4 \%$ in rural women. In 1968 obesity was found in more than a third of local respondents (38.6\%). In 1989, a 51\% prevalence of obesity was found with a ratio of 2 women:1 man, reaching more than $43 \%$ of diabetic patients, highlighting in this study that in Yucatan there is a short stature, probably due to a nutritional component, genetic due to high consanguinity, or, from the preHispanic era ${ }^{[7-9,22-32]}$.

Another study carried out by Laviada in medical students reports that $34.1 \%$ of students with a family history of type 2 diabetes mellitus exceeded their ideal weight and only $20.3 \%$ of those without such a history were above their ideal weight ${ }^{[12]}$.

Body fat fulfills many functions, among which are: conservation of heat, protection of target organs and being a constituent of cells in the body. Fat is only harmful when it exists in excess in the body, in general and particularly at the intra-abdominal and periportal level. Until recently it was considered that it was the direct result of a sedentary life coupled with a chronic ingestion of kilocalories that causes an imbalance between the energy that enters and the energy that leaves. Although there is no doubt that these factors are the main cause, many other factors have now been found to play a role in their etiology ${ }^{[23]}$.

Increased deposits of adipose tissue are found in subcutaneous tissue, around internal organs, in the momentum and in intramuscular spaces, with greater amounts of lean body mass, as evidenced by a greater increase in kidneys, heart, liver and skeletal muscle mass up to hepatic steatosis (fatty liver). The increase in adipose tissue has been shown to exist only during a limited period of early childhood and perhaps during puberty. Therefore, before reaching adulthood, the possibility of an increase in the number of adipocytes decreases. From this moment on, the expansion of the adipose mass is mainly achieved by the increase in the size of the fat cells ${ }^{[23-25]}$. 
There is a genetic or hereditary background that includes several genes such as leptin (satiety protein only produced in adipose tissue) that are involved in the regulation of energy that causes greater metabolic efficiency so that it cannot be dissipated in the form of heat. Once obesity occurs, decreased exercise, which helps to facilitate weight gain, and a psychological picture of fat maintenance are also important ${ }^{[26-29]}$.

According to its etiology, obesity is classified as: 1. Essential obesity; and 2. Secondary obesity. Essential obesity is the most common and constitutes more than $95 \%$ of clinical obesity cases. It results from a complex interaction of environmental factors (poor diet, sedentary habits, psychological factors and sociocultural factors) associated with genetic predisposition. When the intake of kilocalories exceeds the expenditure, the excess of kilocalories is deposited in the adipose tissue and if this positive balance is maintained there is obesity. Normal daily caloric needs range from 110 to 139 Kilojoules (26.290633.2218 kilocalories) per kilogram of weight, the figure is higher in people who perform physical activities and lower in sedentary people. 1 Kilojoule $=0.239006$ kilocalories ${ }^{[7,30-31]}$.

According to the distribution of body fat measured by the Waist/Hip Index, obesity is classified as: 1. Android; and 2. Gynecoid. Android obesity, or obesity predominantly in the upper body segment, is a risk factor for the development of arterial hypertension, glucose intolerance, type 2 diabetes mellitus, hyperlipidemia, and arterial damage. Gynecoid obesity is, to date, considered a minor cardiovascular risk factor ${ }^{[8]}$.

As there is no infallible value that diagnoses obesity, several methods must be used in a complementary way to have a more complete and reliable clinical approach. At present, various techniques are used to measure body fat such as Computed Axial Tomography and Nuclear Magnetic Resonance, which are useful to determine intra-abdominal and subcutaneous fat and are correlated with the Waist/Hip Index that is used as an indicator of fat distribution. However, they come at great cost and expertise from the medical staff. Other methods are the measurements of the skin folds (subscapularis, biceps and suprailiac, among others), which are equally highly experienced and precise for their performance and determination are highly variable between individuals ${ }^{[9,32]}$.

\section{ANTHROPOMETRIC INDICES}

There are indicators that are easier to perform and exceptionally reliable as a diagnosis and risk indicators in obesity which are based on measurements and proportions of the body. Among the main ones are:

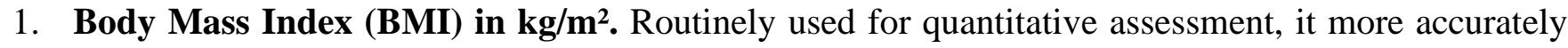
reflects excess adipose tissue. However, it is altered in the case of high muscle mass and edema and 
probably varies with age. Using this method, $5.8 \%$ and $8.3 \%$ of men and women are obese. It is calculated by dividing the weight (in kilograms) by the square of the height (in meters) and is expressed in kilograms/square meters $\left(\mathrm{kg} / \mathrm{m}^{2}\right)$. The Body Mass Index considered "optimal" ranges from 22 to 23; the considered "normal" is 27.8 in men and 27.3 in women -values accepted by the Obesity Clinic of the "Salvador Zubirán" National Institute of Nutrition [9]. Through the Body Mass Index, which is a simple way of measuring overweight and obesity in adults, the National Institutes of Health of the United States of North America defines overweight as a Body Mass Index of 25.00 to $27.00 \mathrm{~kg} / \mathrm{m}^{2}$ and obesity as a relative weight $120 \%$ (Body Mass Index= $27.50 \mathrm{~kg} / \mathrm{m}^{2}$ ); to "mild obesity" from 121 to $140 \%$ (Body Mass Index between 27.60 and $30.00 \mathrm{~kg} / \mathrm{m}^{2}$ ); to "moderate obesity" from 141 to $200 \%$ (Body Mass Index between 30.10 and $40.00 \mathrm{~kg} / \mathrm{m}^{2}$ ); and "severe obesity" $\geq 200 \%$ (Body Mass Index $\geq 40.00 \mathrm{~kg} / \mathrm{m}^{2}$ ). An especially important aspect of obesity is the distribution of body fat, since the central or abdominal location is associated with a high risk of cardiovascular complications, dyslipidemias, insulin resistance, high blood pressure, type 2 diabetes mellitus and metabolic syndrome. Also, in moderate obesity the android silhouette predominates but, in severe obesity, the index has little value since fat accumulates throughout the body. The importance of central obesity is clear in some populations (Asia) where the Body Mass Index is relatively low. However, the levels of abdominal fat are high and present the complications mentioned. A recent study conducted in India revealed that $20 \%$ of adults who are not obese, or overweight are nevertheless centrally obese and are at high risk of developing the above complications. Therefore, there are abdominal measurement indices that, carried out correctly, reflect cardiovascular risk and risk of chronic disease according to certain changes and that, together with the Body Mass Index, allow the identification of high-risk biases for health. Similarly, it is especially important to identify the gender [9, 32].

2. Waist/Hip Index (ICC) in units. The Waist/Hip Index is a specific anthropometric measure to measure intra-abdominal fat levels. Mathematically, it is a ratio to divide the waist circumference by the hip circumference. There are two types of obesity according to the body fat distribution pattern: 1. Android; and 2. Gynecoid. The first type is called intra-abdominal or visceral obesity and the second is called extra-abdominal or subcutaneous obesity. To quantify it, it has been seen that an anthropometric measure such as the Waist/Hip Index correlates well with the amount of visceral fat, which makes this ratio a feasible measurement from a practical point of view. This measure is complementary to the Body Mass Index, since the Body Mass Index does not distinguish whether overweight is due to physiological (healthy) muscle hypertrophy, as is the case in athletes, or to an increase in pathological (unhealthy) body fat. The WHO establishes normal levels for the Waist/Hip 
Index of $\leq 0.92$ units in men and $\leq 0.83$ units in women. Higher values indicate abdominovisceral obesity, which is associated with an increased cardiovascular risk and an increased probability of contracting diseases such as type 2 diabetes mellitus and arterial hypertension. The index is obtained by measuring the perimeter of the waist at the level of the last floating rib and the maximum perimeter of the hip at the level of the buttocks. Waist/Hip Index= Waist (in $\mathrm{cm}$ )/Hip (in cm) ${ }^{[9,32]}$.

3. Abdominal Circumference (AC) in cm. The Spanish Heart Foundation (FEC) warns that the area of the body in which fat is accumulated is a more important cardiovascular risk factor than excess weight (overweight or obesity) and therefore recommends measuring the abdominal perimeter instead to calculate only the Body Mass Index. Depending on the location of the excess fat there are two types of obesity: 1. The so-called peripheral (excess fat is in the buttocks, thighs and arms); and 2. The central one (excess fat is concentrated in the abdomen). The latter is the one that has the worst consequences for the body, since various studies have shown that excess abdominal fat can double the risk of suffering from cardiovascular disease. The fat accumulated around some of the main organs of the body, called visceral fat, promotes changes in cholesterol, increased triglycerides, increased risk of type 2 diabetes mellitus, increased blood pressure and risk of thrombosis. All these factors favor the development of cardiovascular disease. This accumulation of fat is a consequence of genetic and hormonal factors and of following unhealthy lifestyles such as poor diet, tobacco consumption, sedentary lifestyle and stress, among others. The abdominal girth can be easily measured with a tape measure. The person should stand with their feet together, their arms at their sides and their abdomen relaxed, then wrap the measuring tape around their abdomen at the level of the navel and without pressing, take a deep breath and immediately draw the air. The WHO establishes the maximum healthy values for abdominal girth at $\leq 93 \mathrm{~cm}$ in men and $\leq 79 \mathrm{~cm}$ in women ${ }^{[9,32]}$.

\section{GENERAL OBJECTIVE}

To statistically compare the internal validity (sensitivity, specificity and safety) of the Body Mass Index versus the internal validity of the Waist/Hip Index and versus the internal validity of the Abdominal Circumference as diagnostic methods of overweight and obesity in adults of 18-64 years of age of either gender who attended the Integral Hospital "Jose Maria Morelos" of the Mayan municipality of Jose Maria Morelos, Quintana Roo, Mexico, in the period from August 1, 2017 to July 31, 2018.

\section{SPECIFIC OBJECTIVES}

1. Calculate the sensitivity, specificity and safety values of the Body Mass Index;

2. Calculate the sensitivity, specificity and safety values of the Waist/Hip Index; 
3. Calculate the sensitivity, specificity and safety values of the Abdominal Circumference;

4. Use the Mantel-Haenszel Chi-Square statistic $\left(\mathrm{x}^{2} \mathrm{M}-\mathrm{H}\right)$ as a test of hypothesis or test of statistical significance to compare the values of the sensitivity, the specificity and the safety of the Body Mass Index versus the values of the sensitivity, the specificity and safety of the Waist/Hip Index;

5. Use the Mantel-Haenszel Chi-Square statistic $\left(\mathrm{x}^{2} \mathrm{M}-\mathrm{H}\right)$ as a test of hypothesis or test of statistical significance to compare the values of the sensitivity, specificity and safety values of the Body Mass Index versus the sensitivity, the specificity and the safety of the Abdominal Circumference; and

6. Use the Mantel-Haenszel Chi-Square statistic $\left(\mathrm{x}^{2} \mathrm{M}-\mathrm{H}\right)$ as a test of hypothesis or test of statistical significance to compare the values of the sensitivity, the specificity and the safety of the Waist/Hip Index versus the values of the sensitivity, the specificity and safety of the Abdominal Circumference.

\section{HYPOTHESIS FORMULATION}

\subsection{NULL HYPOTHESES $\left(\mathrm{H}_{0}\right)$}

1. There is no or no statistically significant evidence at the significance level $(\alpha)$ of $5 \%$ to assume that the sensitivity, specificity and safety of the Body Mass Index are different from the sensitivity, specificity and safety of the Waist Index/Hip;

2. There is no or no statistically significant evidence at the significance level $(\alpha)$ of $5 \%$ to assume that the sensitivity, specificity and safety of the Body Mass Index are different from the sensitivity, specificity and safety of Circumference Abdominal ; and

3. There is no or no statistically significant evidence at the $5 \%$ level of significance $(\alpha)$ to assume that the sensitivity, specificity and safety of the Waist/Hip Index are different from the sensitivity, specificity and safety of the Circumference Abdominal .

\section{5..2 ALTERNATIVE HYPOTHESES, WORKING HYPOTHESES OR RESEARCH HYPOTHESES}

$\left(\mathrm{H}_{1}\right)$

1. There is or exists statistically significant evidence at the $5 \%$ level of significance $(\alpha)$ to assume that the sensitivity, specificity and safety of the Body Mass Index are different from the sensitivity, specificity and safety of the Waist/Hip Index;

2. There is or exists statistically significant evidence at the significance level $(\alpha)$ of $5 \%$ to assume that the sensitivity, specificity and safety of the Body Mass Index are different from the sensitivity, specificity and safety of the Abdominal Circumference; and 
3. There is or exists statistically significant evidence at the $5 \%$ level of significance $(\alpha)$ to assume that the sensitivity, specificity and safety of the Waist/Hip Index are different from the sensitivity, specificity and safety of the Abdominal Circumference.

\section{MATERIAL AND METHODS}

\section{-Epistemological approach}

Quantitative approach, probabilistic approach or positivist approach ${ }^{[33]}$.

\section{-Study design}

Descriptive observational epidemiological study with no directionality and prospective temporality ${ }^{[34]}$.

\section{-Study universe}

The study was conducted in 300 adult patients [119 (39.67\%) of the male gender and $181(60.33 \%)$ of the female gender] aged 18-64 years who attended the Integral Hospital "Jose Maria Morelos" of the Mayan municipality of Jose Maria Morelos, Quintana Roo, Mexico, in the period from August 1, 2017 to July 31, 2018.

\section{-Techniques and procedures}

The necessary information was collected at the Integral Hospital "Jose Maria Morelos" in the Mayan municipality of Jose Maria Morelos, Quintana Roo, Mexico. The study population consisted of 300 adult patients (18-64 years of age), both male and female, who attended the Health Services Institution during the period from August 1, 2017 to July 31, 2018.

\section{-Data processing}

In the elaboration stage, the data were reviewed (information quality control); classified (on qualitative and quantitative scales); computerized (IBM SPSS Statistics software for Windows, Version 22 was used); presented (in Tables and Figures); and summarized (the corresponding summary measures were used for data classified in qualitative and quantitative scales). In the analysis and interpretation stages, the data were analyzed and interpreted, respectively.

$2 \times 2$ contingency tables were constructed from which the sensitivity, specificity, and safety were calculated for each of the three diagnostic tests. The Mantel-Haenszel Chi-Square statistic $\left(\mathrm{x}^{2} \mathrm{M}-\mathrm{H}\right)$ was used as a hypothesis test or a test of statistical significance. The Epi lnfo software for Windows, Version 7.1.5.2, was used to obtain the values of the statistic $\mathrm{x}^{2} \mathrm{M}-\mathrm{H}$ and the values of the probabilities $(p)$. The criterion applied in carrying out the hypothesis tests for the difference between two percentages was based on the following recommendations made by Cochran ${ }^{[35]}: 1$. When $\mathrm{N}>40$ use the $\mathrm{x}^{2} \mathrm{M}-\mathrm{H}$ test; 2 . When 20 


$$
\begin{gathered}
\mathrm{X}^{2} \mathrm{M} \mathrm{H}=\sum(|\mathrm{O}-\mathrm{E}| 0.5)^{2} / \mathrm{E} \text {; and } \\
\operatorname{PPEF}=(\mathrm{A}+\mathrm{B}) !(\mathrm{C}+\mathrm{D}) !(\mathrm{A}+\mathrm{C}) !(\mathrm{B}+\mathrm{D}) ! / \mathrm{N} ! \mathrm{A} ! \mathrm{B} ! \mathrm{C} ! \mathrm{D} !
\end{gathered}
$$

Table 1. Contingency table of $2 \times 2$ according to letters A, B, C and D by disease according to results of the diagnostic test

\begin{tabular}{|l|c|c|c|}
\hline \multirow{2}{*}{ Diagnostic Test Results } & \multicolumn{2}{|c|}{ Disease } & \multirow{2}{*}{ Totals } \\
\cline { 2 - 3 } & Present & Absent & A + B \\
\hline Positive & A & B & C + D \\
\hline Negative & C & D & $\mathrm{N}=\mathrm{A}+\mathrm{B}+\mathrm{C}+\mathrm{D}$ \\
\hline Totals & $\mathrm{A}+\mathrm{C}$ & $\mathrm{B}+\mathrm{D}$ & \\
\hline
\end{tabular}

SOURCE. Own elaboration

Table 2. $2 \times 2$ contingency table according to true positives, false positives, false negatives and true negatives due to disease according to the results of the diagnostic test.

\begin{tabular}{|l|c|c|c|}
\hline \multirow{2}{*}{ Diagnostic Test Results } & \multicolumn{2}{|c|}{ Disease } & \multirow{2}{*}{ Totals } \\
\cline { 2 - 4 } & Present & Absent & Total positives \\
\hline Positive & True positives & False positives & Total negatives \\
\hline Negative & False negatives & True negatives & Grand total \\
\hline Totals & Total sick & Total healthy & \\
\hline
\end{tabular}

SOURCE. Own elaboration

True positives (A). Observation units with the characteristic of interest (disease) that are correctly identified as positive by the diagnostic test;

False positives (B). Observation units without the characteristic of interest (disease) that are incorrectly identified as positive by the diagnostic test;

False negatives (C). Observation units with the characteristic of interest (disease) that are incorrectly identified as negative by the diagnostic test;

True negatives (D). Observation units without the characteristic of interest (disease) that are correctly identified as negative by the diagnostic test;

Sensitivity $(\mathrm{A} / \mathrm{A}+\mathrm{C}) * 100$. Capacity of the diagnostic test to correctly identify those who do suffer from the disease. It is obtained by multiplying by 100 the quotient obtained by dividing the number of true positives $(\mathrm{A})$ by the total number of patients $(\mathrm{A}+\mathrm{C})$;

Specificity $(\mathrm{D} / \mathrm{B}+\mathrm{D}) * 100$. Capacity of the diagnostic test to correctly identify those who do not suffer from the disease. It is obtained by multiplying by 100 the quotient obtained by dividing the number of true negatives $(\mathrm{D})$ by the total of healthy ones $(\mathrm{B}+\mathrm{D})$; and 
Safety $(\mathrm{A}+\mathrm{D}) /(\mathrm{N}) * 100$. The safety of a diagnostic test is determined by the positive predictive value and by the negative predictive value. These indices are important to assess the usefulness of a diagnostic test in the clinical field and individually, that is, for each patient.

\section{RESULTS}

Three husband observation units of 18-64 years of age of both genders were studied in the period from August 1, 2017 to July 31, 2018. The absolute frequencies and relative frequencies of the 300 observation units were 119 (39.67\%) and 181 (60.33\%) for the male and female genders, respectively. According to the Norma Oficial Mexicana NOM-174-SSA1-1998, 171 (57.00\%) observation units were labeled with overweight and obesity and 129 (43.00\%) observation units without overweight and obesity.

Table 3 shows the absolute frequencies and relative frequencies of the 300 observation units for pathological nutritional situations, overweight and obesity (Norma Oficial Mexicana NOM-174-SSA11998) according to Body Mass Index. Of the 300 observation units studied, and according to the operational definition of the variables ${ }^{[11]}, 171(57.00 \%)$ and $129(43.00 \%)$ were labeled, respectively, as pre-obese and obese ( $\geq 20 \%$ overweight) and as not-pre-obese and non-obese $(\leq 19 \%$ overweight). On the other hand, according to the operational definition of the variable Body Mass Index ${ }^{[32]}, 199$ (66.33\%) and 101 (33.67\%) observation units were labeled, respectively, with values of Body Mass Index $\geq 25.00$ $\mathrm{kg} / \mathrm{m}^{2}$ and Body Mass Index $\leq 24.99 \mathrm{~kg} / \mathrm{m}^{2}$.

Table 3. Absolute frequencies and relative frequencies of the 300 observation units for pathological nutritional situations, overweight and obesity (Norma Oficial Mexicana NOM-174-SSA1-1998) according to Body Mass Index (in kg/m²).

\begin{tabular}{|l|c|c|c|}
\hline \multirow{2}{*}{$\begin{array}{c}\text { BODY MASS INDEX } \\
\left(\text { in } \mathrm{kg} / \mathrm{m}^{2}\right)\end{array}$} & \multicolumn{2}{|c|}{ Norma Oficial Mexicana NOM-174-SSA1-1998 } & \multirow{2}{*}{ Totals } \\
\cline { 2 - 4 } & Yes & No & \multirow{2}{*}{$199(66.33 \%)$} \\
\hline Positive $\geq 25.00 \mathrm{~kg} / \mathrm{m}^{2}$ & $141(82.46 \%)$ & $58(44.96 \%)$ & $101(33.67 \%)$ \\
\hline Negative $\leq 24.99 \mathrm{~kg} / \mathrm{m}^{2}$ & $30(17.54 \%)$ & $71(55.04 \%)$ & $300(100.00 \%)$ \\
\hline Totals & $171(57.00 \%)$ & $129(43.00 \%)$ & \\
\hline
\end{tabular}

SOURCE. Own elaboration

The absolute frequencies and the relative frequencies of the 300 observation units for pathological nutritional situations, overweight and obesity (Norma Oficial Mexicana NOM-174-SSA1-1998) according to the Waist/Hip Index are presented in Table 4. Of the 300 observation units studied, and according to the operational definition of the variables [11], $171(57.00 \%)$ and $129(43.00 \%)$ were labeled, respectively, as overweight and obesity ( $\geq 20 \%$ overweight $)$ and as non-pre-obese and non-obese $(\leq 19 \%$ overweight). On the other hand, according to the operational definition of the variable Waist/Hip Index ${ }^{[32]}, 177(59.00 \%)$ and $123(41.00 \%)$ observation units were labeled, respectively, with values of 
Waist/Hip Index $\geq 93$ units in men and $\geq 84$ units in women and Waist/Hip Index $\leq 92$ units in men and $\leq 83$ units in women.

Table 4. Absolute frequencies and relative frequencies of the 300 observation units for pathological nutritional situations, overweight and obesity (Norma Oficial Mexicana NOM-174-SSA1-1998) according to the Waist/Hip Index.

\begin{tabular}{|c|c|c|c|}
\hline \multirow[b]{3}{*}{$\begin{array}{l}\text { WAIST/HIP INDEX } \\
\text { (in units) }\end{array}$} & \multirow{2}{*}{\multicolumn{2}{|c|}{$\frac{\text { Norma Oficial Mexicana NOM-174-SSA1-1998 }}{\text { Overweight and obesity }}$}} & \multirow[b]{3}{*}{ Totals } \\
\hline & & & \\
\hline & Yes & No & \\
\hline $\begin{array}{l}\text { Positive } \\
\text { Men } \geq 93 \text { units } \\
\text { Women }>84 \text { units }\end{array}$ & $123(71.93 \%)$ & $54(41.86 \%)$ & $177(59.00 \%)$ \\
\hline $\begin{array}{l}\text { Negative } \\
\text { Men } \leq 92 \text { units }\end{array}$ & $48(2807 \%)$ & $75(58.14 \%)$ & $123(4100 \%)$ \\
\hline Totals & $171(57.00 \%)$ & $129(43.00 \%)$ & $300(100.00 \%)$ \\
\hline
\end{tabular}

SOURCE. Own elaboration

Table 5 shows the absolute frequencies and the relative frequencies of the 300 observation units for pathological nutritional situations, overweight and obesity (Norma Oficial Mexicana NOM-174SSA1-1998) according to Abdominal Circumference. Of the 300 observation units studied, and according to the operational definition of the variables ${ }^{[11]}, 171(57.00 \%)$ and $129(43.00 \%)$ were labeled, respectively, as pre-obese and obese ( $\geq 20 \%$ overweight) and as not-pre-obese and non-obese $(\leq 19 \%$ overweight). On the other hand, according to the operational definition of the Abdominal Circumference variable $^{[32]}, 202$ (67.33\%) and 98 (32.67\%) observation units were labeled, respectively, with Abdominal Circumference values $\geq 94 \mathrm{~cm}$ in men and $\geq 80 \mathrm{~cm}$ in women and Abdominal Circumference $\leq 93 \mathrm{~cm}$ in men and $\leq 79 \mathrm{~cm}$ in women.

Table 5. Absolute frequencies and relative frequencies of the 300 observation units for pathological nutritional situations, overweight and obesity (Norma Oficial Mexicana NOM-174-SSA1-1998) according to Abdominal Circumference.

\begin{tabular}{|c|c|c|c|}
\hline \multirow{3}{*}{$\begin{array}{c}\text { ABDOMINAL } \\
\text { CIRCUMFERENCE } \\
\text { (in } \mathrm{cm} \text { ) }\end{array}$} & \multirow{2}{*}{\multicolumn{2}{|c|}{$\begin{array}{c}\text { Norma Oficial Mexicana NOM-174-SSA1-1998 } \\
\text { Overweight and Obesity }\end{array}$}} & \multirow[b]{3}{*}{ Totals } \\
\hline & & & \\
\hline & Yes & No & \\
\hline $\begin{array}{l}\text { Positive } \\
\text { Men } \geq 94 \mathrm{~cm} \\
\text { Women } \geq 80 \mathrm{~cm}\end{array}$ & $138(80.70 \%)$ & $64(49.61 \%)$ & $202(67.33 \%)$ \\
\hline $\begin{array}{l}\frac{\text { Negative }}{\text { Men } \leq 93 \mathrm{~cm}} \\
\text { Women } \leq 79 \mathrm{~cm}\end{array}$ & $33(19.30 \%)$ & $65(50.39 \%)$ & $98(32.67 \%)$ \\
\hline Totals & $171(57.00 \%)$ & $129(43.00 \%)$ & $300(100.00 \%)$ \\
\hline
\end{tabular}




\section{DISCUSSION}

Three husband observation units were studied [119 (39.67\%) of the male gender and $181(60.33 \%)$ of the female gender] aged 18-64 years who attended the Integral Hospital "Jose Maria Morelos" in the period from August 1 from 2017 to July 31, 2018.

The general objective was to statistically compare the three components of internal validity (sensitivity, specificity and safety) of the Body Mass Index versus the Waist/Hip Index and versus the Abdominal Circumference as diagnostic methods of overweight and obesity in adults aged 18-64 years of age of either gender.

In ascending numerical order, the sensitivities observed were 71.93\% (123/171) for the Waist/Hip Index; 80.70\% (138/171) for Abdominal Circumference; and 82.46\% (141/171) for the Body Mass Index.

When the observed sensitivity of the Body Mass Index (82.46\%) was compared with the observed sensitivity of the Waist/Hip Index (71.93\%), a statistically significant difference was found: $\mathrm{x}^{2} \mathrm{M}-\mathrm{H}(\alpha=$ $0.0500 ; \mathrm{df}=1)>3.8416 ; p<0.0500$. On the other hand, no statistically significant difference was found when the observed sensitivity of the Body Mass Index (82.46\%) was compared with the sensitivity of the Abdominal Circumference (80.70\%): $\mathrm{x}^{2} \mathrm{M}-\mathrm{H}(\alpha=0.0500 ; \mathrm{df}=1)<3.8416 ; p>0.0500$. Finally, no statistically significant difference was found when comparing the observed sensitivity of the Waist/Hip Index $(71.93 \%)$ versus the observed sensitivity of the Abdominal Circumference $(80.70 \%): \mathrm{x}^{2} \mathrm{M}-\mathrm{H}(\alpha=$ $0.0500 ; \mathrm{df}=1)<3.8416 ; p>0.0500$.

The specificities observed, in ascending numerical order, were 50.39\% (65/129) for Abdominal Circumference; 55.04\% (71/129) for the Body Mass Index; and 58.14\% (75/129) for the Waist/Hip Index. No statistically significant differences were found when the observed specificities of the three diagnostic methods were compared: $\mathrm{x}^{2} \mathrm{M}-\mathrm{H}(\alpha=0.0500 ; \mathrm{df}=1)<3.8416 ; p>0.0500$.

Finally, always in ascending numerical order, the observed securities were 66.00\% (198/300) for the Waist/Hip Index; $67.67 \%$ (203/300) for Abdominal Circumference; and 70.67\% (212/300) for the Body Mass Index. No statistically significant differences were found when the observed assurances of the three diagnostic methods were compared: $\mathrm{x}^{2} \mathrm{M}-\mathrm{H}(\alpha=0.0500 ; \mathrm{df}=1)<3.8416 ; p>0.0500$.

In the present work, the lowest and highest sensitivities were found, respectively, for the diagnostic tests Waist/Hip Index (71.93\%) and Body Mass Index (82.46\%).

The lowest and highest specificities were found, respectively, for the diagnostic tests Abdominal Circumference (50.39\%) and Waist/Hip Index (58.14\%).

Finally, the lowest and highest securities were found, respectively, for the diagnostic tests Waist/Hip Index (66.00\%) and Body Mass Index (70.67\%). 
Despite not having the greatest capacity to correctly identify those who do not suffer from the disease (specificity), the results obtained indicate that the Body Mass Index is the diagnostic test that has the greatest capacity to correctly identify those who do suffer from the disease (sensitivity) (82.46\%). In addition, the Body Mass Index is the diagnostic test that resulted with the greatest security (70.67\%), that is, with the highest proportion of true positives and true negatives with respect to the total observation units studied. As if that were not enough, the specificity of the Body Mass Index (55.04\%) did not result with a statistically significant difference when compared with the specificity of the Waist/Hip Index $(58.14 \%)$, that is, the diagnostic test that resulted with the greatest capacity. to correctly identify those who do not suffer from the disease. 


\section{REFERENCES}

Baron RB. Un nutrición en Kupp; Diagnóstico and Tratamiento Clínico; Editorial El Manual Moderno; Trigésima Edición; México, D.F.; 1995; pp. 1099-911.

Jerrold MO. "Obesidad" en Harrison, Principios de Medicina Interna; Editorial Interamericana; Decimocuarta Edición; México, D.F.; 1998; pp. 1435-1437.

Hernández de Valera and Hernández HR. Relación del índice cintura/cadera con la masa and el porcentaje de grasa corporal; Revista Archivos Latinoamericanos de Nutrición; volumen 47; número 4; 1997; pp. $315-321$.

http://www.spin.eom.mx/ipgutierrez/sabores/obesjdad.htm.publica

González-Villalpando C, Stern PM. "La obesidad como factor de riesgo cardiovascular en México"; La Revista de Investigación Clínica; 1993; volumen 45; número 1; pp. 13-21.

Chávez A, Díaz D. Frecuencia de obesidad en algunas zonas de la República Mexicana; Revista Clínica de Investigación; número 19; 1987; pp. 119-129.

Avila RH. Epidemiología de la obesidad en México; Cuadernos de Nutrición; volumen 20; número 6; Noviembre-Diciembre 1998; México; pp. 8-12.

Casillas LE, Vargas LA. La distribución de la grasa corporal, posible factor de riesgo para la salud; Cuadernos de Nutrición; volumen 16; número 6; Noviembre-Diciembre 1993; México; pp. 7-15.

Vargas LA, Casillas LE. Indicadores antropométricos del déficit and exceso de peso en el adulto para empleo en la consulta and en el campo; Cuadernos de Nutrición; volumen 16; número 5; SeptiembreOctubre 1996; México; pp. 34-43.

\section{Norma Oficial Mexicana NOM-174-SSA1-1998}

Berkow R, Beers MH, Fletcher AJ. The Merck Manual - Home Edition. Océano Grupo Editorial, S.A.; España; 1997; pp. 715-717.

Laviada H, Vargas 1, Laviada E. Estudio preliminar de diabetes mellitus en familiares de estudiantes de medicina; XXVII Reunión Anual de la Sociedad Mexicana de Nutrición and Endocrinología; 1987.

Hard Ir, Newton RW. Endocrinología: Sistema Integrado de Estudio; Editorial El Manual Moderno; Primera Edición; México, D.F.; 1987.

Bronwell KD, Waden TA. La heterogeneidad de la Obesidad, Tratamiento de ajuste individual, Terapia de Comportamientos; Revista número 22; México, D.F.; 1991; pp. 153-177.

http://www.obesidades.com/ioft.htm

Stunkard. Algunas perspectivas sobre la obesidad humana, sus causas; Revista Americana, Boletín de la Academia de Medicina de New York; número 64; 1988; pp. 902-923. 
Cuyngarden JB, Smith H, Cecil. Tratado de Medicina Interna; Decimoctava Edición; Editorial Interamericana; volumen 1; Madrid, España; 1991.

Laviada EA. Encuesta de Diabetes en Mérida; VII Reunión Anual de la Sociedad Mexicana de Nutrición and Endocrinología; Escuela de Medicina de la Universidad Autónoma de Yucatán; Hospital Escuela O'Horán e Instituto Nacional de la Nutrición; números 29 and 30; Guanajuato, Guanajuato; 1978.

Castro-Villalobos F. El índice de masa corporal como criterio diagnóstico de obesidad en nuestra población; Tesis profesional; Universidad Autónoma de Yucatán; 1990.

Brunzel Id, Schawtz RG. Balance, almacén and transporte de la energía; Textos de Fisiología; 1989; pp. 1544-1561.

Lachance AP. Tecnología de alimentos en obesidad humana; volumen 48; número 28; 1994.

Arroyo P, Represa J. "Nutrición Clínica"; Memorias de un Simposio Internacional; Primera Edición; Editorial Interamericana; México, D.F.; 1994.

Ramos-Carricarte A. Obesidad "Conceptos Actuales"; Página Electrónica, México, D.F.; 1998.

Bray G. "Obesidad" en Harrison; Principios de Medicina Interna; Editorial Mcgraw-Hill; Interamericana; Decimocuarta Edición; volumen 1; Madrid, España; 1998; pp. 565-570.

http://www.tamnet.corn.mx/-rossell/nutricion.htm

Bjortorp, Pern. Obesity Seminar; Revist The Lancet; volumen 1; número 350; 1997; pp. 423-426.

Despres JP, Krauss RM. Obesity and Lipoprotein Metabolism; University of Quebec, Canadá and California; pp. 657-671.

Bray GA. Fat Distribution and Body Weigth Obesity; volumen 1; número 3; 1994.

http://www.seedo.es/cons.intro.htm

Casa MO, González BJ. La Norma Oficial Mexicana para la Atención de la Obesidad; Cuadernos de Nutrición; volumen 22; número 5; Septiembre-Octubre 1999; México; pp. 221-226.

Maurer PA. Guía Práctica para la Identificación, Evaluación and Tratamiento de la Obesidad; Nutrición Clínica; volumen 2; suplemento 1; México, 1999; pp. 17-18.

Vargas LA, Bastarrachea SA. Obesidad de México; Primera Edición; Impresiones del Sureste; México; 1999; pp. 25-78.

Hernández-Ávila, M. Epidemiología. Diseño and Análisis de Estudios. México: Editorial Médica Panamericana. pp. 78-85. 2007.

Hernández-Sampieri R, Fernández-Collado C, Baptista-Lucio MP. 2014. Metodología de la Investigación. México: McGraw-Hill/Interamericana Editores, S.A. de C.V.

Cochran WG. Some methods for strengthening the common $\mathrm{x}^{2}$ tests. Biometrics $1954 ; 10: 417-451$. 